\title{
Seasonal dynamics of Totten Ice Shelf controlled by sea ice buttressing
}

\author{
Chad A. Greene ${ }^{1}$, Duncan A. Young ${ }^{1}$, David E. Gwyther ${ }^{2}$, Benjamin K. Galton-Fenzi ${ }^{3,4}$, and Donald D. Blankenship ${ }^{1}$ \\ ${ }^{1}$ Institute for Geophysics, Jackson School of Geosciences, University of Texas at Austin, Austin, Texas, USA \\ ${ }^{2}$ Institute for Marine and Antarctic Studies, University of Tasmania, Hobart, Tasmania, Australia \\ ${ }^{3}$ Australian Antarctic Division, Kingston, Tasmania 7050, Australia \\ ${ }^{4}$ Antarctic Climate \& Ecosystems Cooperative Research Centre, University of Tasmania, Hobart, Tasmania 7001, Australia
}

Correspondence: Chad A. Greene (chad@ chadagreene.com)

Received: 18 April 2018 - Discussion started: 4 May 2018

Revised: 15 August 2018 - Accepted: 23 August 2018 - Published: 6 September 2018

\begin{abstract}
Previous studies of Totten Ice Shelf have employed surface velocity measurements to estimate its mass balance and understand its sensitivities to interannual changes in climate forcing. However, displacement measurements acquired over timescales of days to weeks may not accurately characterize long-term flow rates wherein ice velocity fluctuates with the seasons. Quantifying annual mass budgets or analyzing interannual changes in ice velocity requires knowing when and where observations of glacier velocity could be aliased by subannual variability. Here, we analyze 16 years of velocity data for Totten Ice Shelf, which we generate at subannual resolution by applying feature-tracking algorithms to several hundred satellite image pairs. We identify a seasonal cycle characterized by a spring to autumn speedup of more than $100 \mathrm{~m} \mathrm{yr}^{-1}$ close to the ice front. The amplitude of the seasonal cycle diminishes with distance from the open ocean, suggesting the presence of a resistive back stress at the ice front that is strongest in winter. Springtime acceleration precedes summer surface melt and is not attributable to thinning from basal melt. We attribute the onset of ice shelf acceleration each spring to the loss of buttressing from the breakup of seasonal landfast sea ice.
\end{abstract}

\section{Introduction}

Totten Glacier in East Antarctica drains the Aurora Subglacial Basin, which is grounded well below sea level (Young et al., 2011; Roberts et al., 2011) and contains enough ice to raise the global sea level by at least $3.5 \mathrm{~m}$ (Greenbaum et al., 2015). Short-term observations have identified Totten Glacier and its ice shelf (TIS) as thinning rapidly (Pritchard et al., 2009, 2012) and losing mass (Chen et al., 2009), but longer-term observations paint a more complex picture of interannual variability marked by multiyear periods of ice thickening, thinning, acceleration, and slowdown (Paolo et al., 2015; Li et al., 2016; Roberts et al., 2017; Greene et al., 2017a). The current best estimates of Totten Glacier and TIS mass budgets have been calculated using a mosaic of surface velocity measurements collected at different times throughout the year (Rignot et al., 2013); however, these estimates have been built on an unconfirmed assumption that ice velocity does not vary on subannual timescales. Where glacier flow varies throughout the year, it is possible that velocity measurements collected over short time intervals may lead to inaccurate estimates of annual mass balance or incorrect interpretation of interannual changes in velocity. Furthermore, most common methods of ice velocity measurement, such as satellite image feature tracking or in situ GPS measurements taken over the course of a field season, are strongly biased toward summer acquisition and may not accurately represent winter ice dynamics. Wherever seasonal velocity variability exists, it is important to consider how ice velocity is measured, and how the measurements can be interpreted.

Seasonal variations in glacier velocity have been observed in Greenland and Antarctica (e.g., Joughin et al., 2008; Nakamura et al., 2010; Moon et al., 2014; Zhou et al., 2014; Fahnestock et al., 2016), and have been attributed to a number of different mechanisms. On grounded ice, surface meltwater can drain into crevasses or moulins, make its way to 
the bed, pressurize inefficient subglacial hydraulic systems, and allow the glacier to speed up until pressure is reduced (Sohn et al., 1998; Bartholomew et al., 2010; Moon et al., 2014). On floating ice, surface meltwater may also influence ice shelf velocity by percolating through and weakening the ice shelf shear margins (Liu and Miller, 1979; Vaughan and Doake, 1996; Cavanagh et al., 2017). Observations have shown correspondence between seasonal advance and retreat of marine-terminating glaciers and the presence of ice mélange at the glacier terminus (Howat et al., 2010; Cassotto et al., 2015; Moon et al., 2015). The exact mechanisms by which ice mélange can affect glacier dynamics are poorly understood, but modeling studies have shown that the back stress provided by sea ice can prevent calved icebergs from rotating away from the ice front (Amundson et al., 2010), and in some cases can shut down calving entirely (Robel, 2017), causing an appreciable effect on glacier velocity (Todd and Christoffersen, 2014; Krug et al., 2015). For example, the buttressing strength of ice mélange at Store Glacier in Greenland has been estimated at $30-60 \mathrm{kPa}$, which is an order of magnitude below the driving stress of the glacier but is sufficient to cause observable subannual changes in glacier velocity up to $16 \mathrm{~km}$ from the ice front (Walter et al., 2012; Todd and Christoffersen, 2014).

In Antarctica, marine ice is known to strengthen the Brunt and Stancomb-Willis ice shelf system (Hulbe et al., 2005), and an ice shelf acceleration event observed there in the 1970s has been attributed to a reduction in stiffness of the ice mélange that connects the two ice shelves (Khazendar et al., 2009). Similarly, multiyear landfast sea ice is strongly mechanically coupled to Mertz Glacier Tongue (Massom et al., 2010) and may have delayed a major calving event that occurred there in 2010 (Massom et al., 2015). Closer to TIS, two recent major calving events in Porpoise Bay $\left(76^{\circ} \mathrm{S}\right.$, $128^{\circ} \mathrm{E}$ ) were attributed to the breakup of landfast sea ice at the ice shelf termini (Miles et al., 2017), and on the Antarctic Peninsula it has been shown that sea ice can protect ice shelves from fracture induced by ocean swell (Massom et al., 2018). At TIS, long-term changes in calving front position have been reported with a possible connection to local sea ice processes (Miles et al., 2016), but corresponding links to glacier dynamics have not previously been investigated. To our knowledge, there have been no reports of seasonal variability of TIS or any of the mechanisms that may drive TIS variability at subannual timescales. In this paper we find seasonal variability in two independent ice velocity data sets and we consider the potential roles of surface meltwater, ice shelf basal melt, and sea ice buttressing in influencing the flow of TIS at subannual timescales.

\section{Surface velocity observations}

We analyzed surface velocity time series using featuretracking algorithms applied to Landsat 8 and MODIS (Mod- erate Resolution Imaging Spectroradiometer) images. Each image data set was processed separately, using different feature-tracking programs, and the resulting time series represent two independent measures of TIS velocity. The $15 \mathrm{~m}$ resolution of Landsat 8 permits precise displacement measurements over short time intervals, but the relatively brief 4-year Landsat 8 record and limited number of cloud-free images inhibits our ability to separate interannual velocity changes from seasonal variability. The MODIS record contains many cloud-free images per year from 2001 to the present; however, the $250 \mathrm{~m}$ spatial resolution of MODIS images limits measurement precision where ice displacements are small between images. Thus, the two image data sets each offer incomplete but complementary insights into the seasonal dynamics of TIS. Processing methods for each data set are described below.

\subsection{GoLIVE (Landsat 8) velocities}

We used the Global Land Ice Velocity Extraction from Landsat 8 (GoLIVE) data set (Scambos et al., 2016; Fahnestock et al., 2016), which is processed at $600 \mathrm{~m}$ resolution for most of Antarctica. We analyzed the high-confidence vx_masked and vy_masked velocity fields from late 2013 to early 2018 and limited the data set to 143 image pairs separated by $16 \leq \mathrm{d} t \leq 112$ days. Many of the image pairs overlap in time, providing several redundant, semiindependent velocity measurements, particularly throughout the summer months when each image may contribute to multiple image pairs.

To understand the spatial pattern of TIS seasonality, we developed characteristic velocity maps for spring and autumn separately. Spring velocity was taken as the mean of 76 velocity measurements for which image pairs were obtained between 16 June and 15 December. Autumn velocity was taken as the mean of 67 velocity fields from images obtained during the remainder of the year. We discard all pixels where the mean ice speed is less than $250 \mathrm{~m} \mathrm{yr}^{-1}$. We also discard all pixels containing fewer than 10 high-confidence spring or autumn velocity measurements. The resulting difference between spring and autumn velocities is shown in Fig. 1.

The terminal $\sim 50 \mathrm{~km}$ of TIS accelerates each year from spring to autumn, then slows during the winter. Seasonality is strongest close to the glacier terminus and decays with distance from the open ocean. The relatively featureless nature of the inner TIS surface limits the number of high-confidence matches in that region of the ice shelf, but the available measurements indicate minimal seasonality upstream of the mid-shelf ice rumple identified by InSAR (Mouginot et al., 2017b). The grounded ice of the eastern tributary accelerates slightly throughout the summer, while some grounded ice of the western tributary exhibits a weak slowdown.

To assess the timing of the annual TIS acceleration, we generate a velocity time series for a region of TIS near the terminus shown in Fig. 1. We populate a velocity time series 


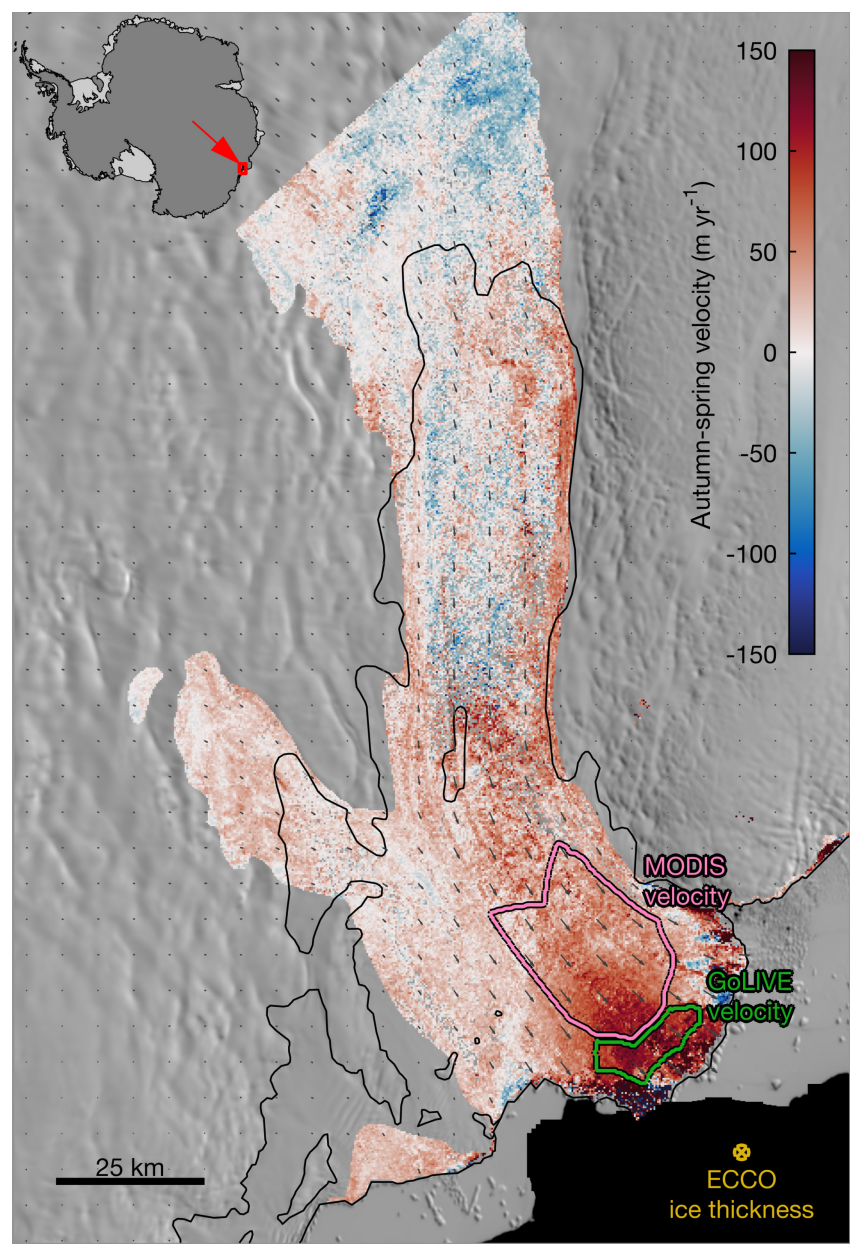

Figure 1. Summer ice shelf acceleration. Toward the calving front (right bottom of the image), autumn velocity exceeds spring velocity by more than $100 \mathrm{~m} \mathrm{yr}^{-1}$. This image shows the difference between the means of 76 spring and 67 autumn GoLIVE velocity fields. Dark green vectors indicate the mean velocity, supplemented by MEaSUREs-InSAR-derived velocity (Rignot et al., 2011) outside the range of Landsat path 102, row 107. Green and pink polygons indicate the bounds of velocity averaging for the velocity time series shown in Figs. 2 and 3. A gold marker shows the location of the ECCO sea ice thickness time series described in Sect. 5. The calving front and grounding line are shown in black, including a grounded ice rumple near the center of the ice shelf (Mouginot et al., 2017b).

from the means of all GoLIVE velocity measurements within 5 to $10 \mathrm{~km}$ from the ice front, considering only pixels with a mean velocity exceeding $1700 \mathrm{~m} \mathrm{yr}^{-1}$. The resulting TIS velocity time series is shown in Fig. 2.

The short record and low temporal resolution of the GoLIVE data set make it difficult to identify the exact timing of the onset of acceleration in any given year, but a linear trend fit to all available measurements indicates a typical acceleration of $0.8 \mathrm{~m} \mathrm{yr}^{-1}$ per day from late September to early April. Further investigation into the timing of accelerations

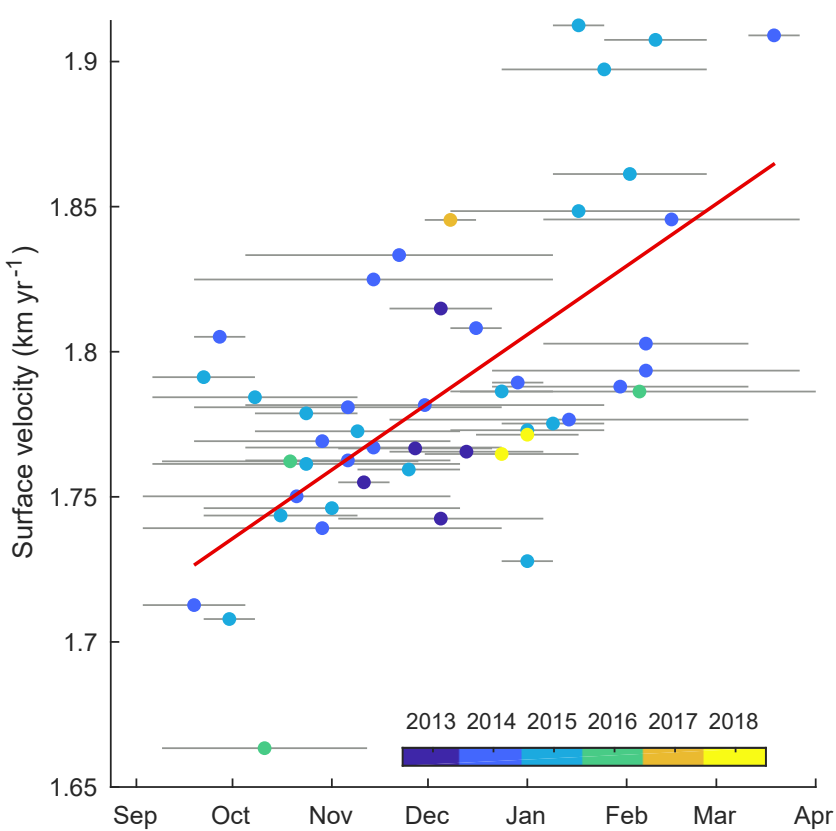

Figure 2. Ice front acceleration from GoLIVE (Landsat 8). The GoLIVE data set contains many overlapping TIS velocity measurements captured between September and April of each year. The velocities here represent all displacements measured over $16 \leq \mathrm{d} t \leq$ 112 days (indicated by gray lines), averaged within the green polygon in Fig. 1. The red trend line is a linear least-squares fit to the observations, indicating a typical spring-to-autumn acceleration of $0.8 \mathrm{~m} \mathrm{yr}^{-1}$ per day.

each year requires a more complete time series of TIS velocity, which we generate from MODIS images.

\subsection{MODIS velocities}

A MODIS velocity time series was generated from 672 pairs of cloud-free MODIS band 2 images (Scambos et al., 2001; Greene and Blankenship, 2018) acquired between 2002 and 2018. Each image pair was separated by 92 to 182 days and was processed at $250 \mathrm{~m}$ resolution using the ImGRAFT template matching software (Messerli and Grinsted, 2015) with Antarctic Mapping Tools for Matlab (Greene et al., 2017b). Similarly to the method described by Greene et al. (2017a), we used $2.5 \mathrm{~km}$ square templates with $4.0 \mathrm{~km}$ search boxes centered on locations predicted by InSAR-derived velocities (Rignot et al., 2017). To generate the MODIS velocity time series we averaged velocities from all pixels within 10 to $30 \mathrm{~km}$ from the ice front, bounded on each side by the glacier shear margins identified by Greene et al. (2017a). We discarded any image pairs for which fewer than $99 \%$ of the pixels within the polygon contained valid displacement measurements, resulting in 565 valid MODIS velocity measurements in the time series. The polygon used for the MODIS time series is shown in Fig. 1. 
Despite having measurements from dozens of MODIS image pairs in most years, subannual template matching applied to $250 \mathrm{~m}$ resolution MODIS images produces such noisy velocity estimates that the timing of springtime acceleration cannot be accurately determined for any given year. However, by combining data from all years we can assess the characteristic cycle of ice shelf acceleration and slowdown that occurs throughout a typical year. Figure 3 shows the MODIS velocity time series overlaid on the mean seasonal cycle. Because no visible-band MODIS images are available during the dark winter months, no image pairs separated by 92 to 182 days are centered on any days in April, May, August, or September. However, 46 image pairs span the winter, providing velocity measurements centered on June and July.

We approximate the seasonal cycle of the TIS velocity as a sinusoid obtained by least squares fit to the 565 MODIS velocity measurements. To minimize the influence of interannual variability, the 1-year moving average was removed before analyzing the seasonal cycle. The resulting best-fit sinusoid is characterized by a $1601 \mathrm{~m} \mathrm{yr}^{-1}$ mean velocity, an amplitude of $106 \pm 9 \mathrm{~m} \mathrm{yr}^{-1}$, a maximum velocity on $21 \mathrm{March}$ ( $1 \sigma=5$ days), and a minimum velocity on 19 September ( $1 \sigma=5$ days). The sinusoid provides a measure of periodicity at the $1 \mathrm{yr}^{-1}$ frequency and matches observations to $r=0.472\left(p=6 \times 10^{-33}\right)$. A complete description of the sinusoid fit and a full uncertainty analysis are provided in Appendix A.

\section{Surface melt observations}

Surface melt has been shown to affect the flow of grounded ice in Greenland when surface water drains through moulins or crevasses to the bed, where it alters basal water pressure and allows the overlying ice to accelerate (Zwally et al., 2002; Schoof, 2010; Bartholomew et al., 2010; Andrews et al., 2014). The seasonal velocity anomalies we observe at TIS are strongest near the floating ice front, so it is unlikely that the seasonal variability of TIS velocity is driven by subglacial hydrology on nearby grounded ice. However, the presence of englacial liquid water can weaken ice (Liu and Miller, 1979), and it is plausible that surface melt at TIS could percolate into the ice, weaken shear margins, and allow TIS to speed up as a result of reduced buttressing.

To assess the possible link between surface melt and TIS velocity anomalies, we used daily observations of surface melt from passive microwave radiometers (SMMR and SSM/I) gridded to $25 \mathrm{~km}$ resolution (Picard and Fily, 2006). We limited the period of analysis to 2000 through 2017 to roughly coincide with available MODIS image data.

Figure 4 shows the spatial distribution of mean annual surface melt during this period. Using the masks developed by Mouginot et al. (2017b) with the Antarctic Mapping Tools for Matlab dist 2mask function (Greene et al., 2017b), we define three subdomains for surface melt analysis as follows:
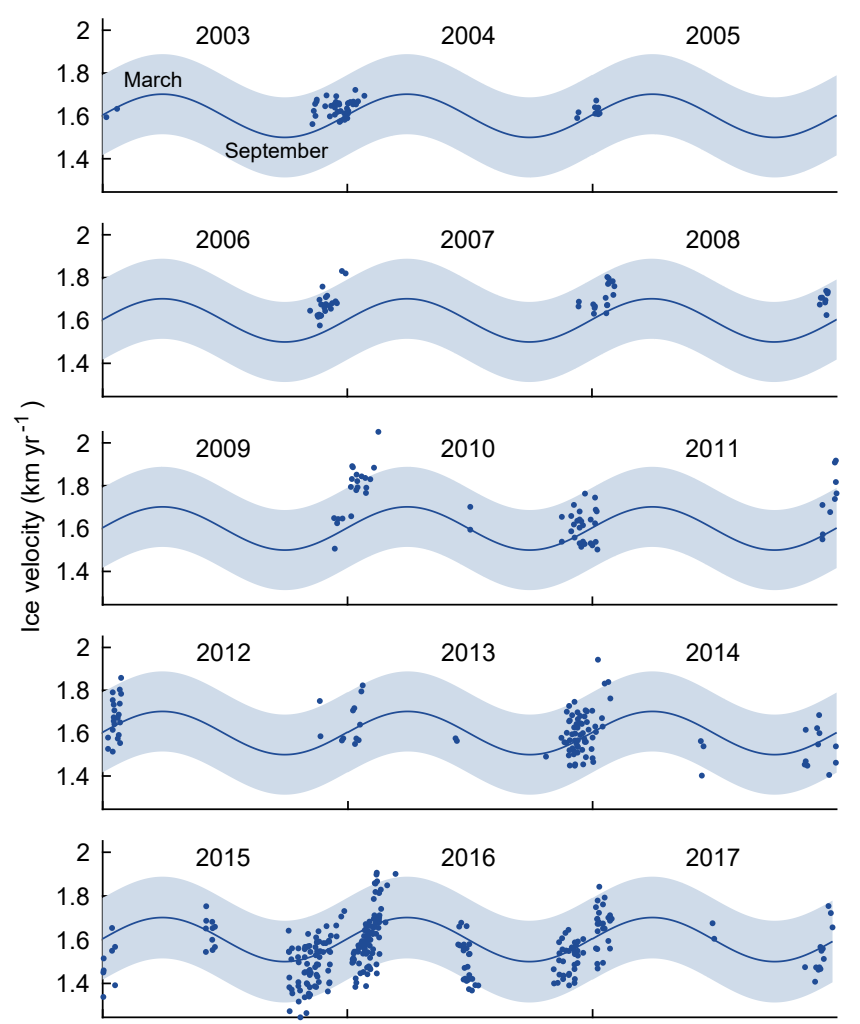

Figure 3. Seasonal cycle of ice shelf velocity from MODIS. TIS velocity measurements from 565 MODIS image pairs separated by 92 to 182 days, averaged within the pink polygon shown in Fig. 1. Velocity measurements are shown at the mean of the acquisition times of their MODIS image pairs. The average seasonal cycle is shown approximated as a sinusoid, with $95 \%$ confidence intervals shaded.

1. outer TIS: the floating portion of the ice shelf up to $50 \mathrm{~km}$ from the ice shelf front,

2. inner TIS: the floating portion of the ice shelf more than $50 \mathrm{~km}$ from the ice shelf front, and

3. grounded: all grounded ice within $50 \mathrm{~km}$ of the TIS grounding line.

Surface melt is most prevalent in the outer TIS, where in some locations surface melt is detected up to 16 days per year. Fewer surface melt days occur far from the ice front on the inner TIS, and surface melt is least common on the highelevation grounded ice surrounding the TIS. Figure 4 shows that, although the number of annual surface melt days varies throughout the region, the timing of surface melt is roughly the same in all three subdomains, with the typical melt season lasting from December to February. For the outer TIS, the onset of surface melt typically occurs on 23 December ( $1 \sigma=12$ days), with the earliest summer melt recorded on 6 December 2006. The mean final day of surface melt occurs on 23 January ( $1 \sigma=9$ days) but has been observed as late as 11 February in 2005. 

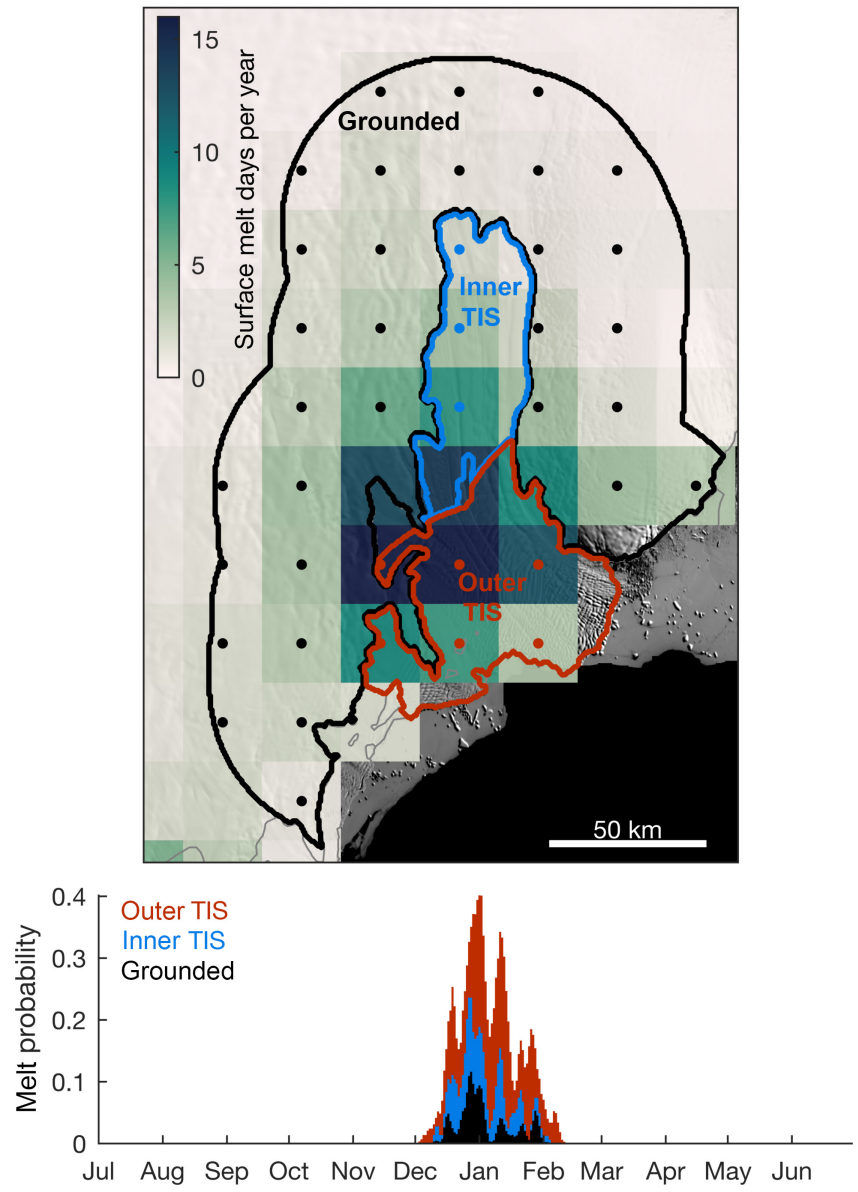

Figure 4. Surface melt observations, 2000-2017. Spatial distribution of mean annual surface melt and daily probability of surface melt in each subdomain. Low-elevation areas near the coast experience more days of surface melt than high-elevation grounded ice, but the timing of surface melt is similar throughout the domain. Data are from Picard and Fily (2006).

\section{Modeled ice shelf basal melt}

On interannual timescales, TIS is known to accelerate in response to prolonged periods of elevated basal melt rates (Roberts et al., 2017; Greene et al., 2017a), and a similar process has been observed at Pine Island Ice Shelf in West Antarctica (Christianson et al., 2016). For these laterallybounded ice shelves restrained largely by shear stress at their margins, thinning reduces resistance to glacier flow and allows ice shelf acceleration.

To assess whether TIS may dynamically respond to basal melt anomalies at subannual timescales, we used the Regional Ocean Modeling System (ROMS; Shchepetkin and McWilliams, 2005) to simulate TIS-ocean interactions, then considered the effects that subannual basal melt anomalies could have on TIS velocity. The model domain extended from 104.5 to $130^{\circ} \mathrm{E}$ in longitude and 60 to $68^{\circ} \mathrm{S}$ in latitude with a horizontal resolution of approximately 2 to $3 \mathrm{~km}$. A

terrain-following vertical coordinate provided enhanced resolution close to the seafloor and ice shelf interface. Modifications to the code allowed thermodynamic interactions between ocean and steady-state ice shelves, following Dinniman et al. (2003) and Galton-Fenzi et al. (2012). Seafloor bathymetry for the deep ocean and continental shelf was taken from the RTopo-1 data set (Timmermann et al., 2010). As RTopo-1 does not contain the cavity of TIS, we inferred the cavity geometry. Ice basal draft for the TIS cavity was obtained from ICESat-derived surface elevations, assuming hydrostatic equilibrium and a mean ice density of $905 \mathrm{~kg} \mathrm{~m}^{-3}$ (following Fricker et al., 2001). Water column thickness was obtained by linearly interpolating the data from $0 \mathrm{~m}$ thick along the grounding line to $300 \mathrm{~m}$ thick along the central flow line of the ice shelf (see Gwyther et al., 2014, for details). The model lateral and surface boundaries were forced over the hindcast period 1992-2012. Lateral forcing was derived from the Estimating the Circulation and Climate of the Ocean phase II (ECCO2) cube92 reanalysis solution (Menemenlis et al., 2008); surface forcing was ERA-Interim wind stress (Dee et al., 2011), and heat and salt fluxes were derived from Special Sensor Microwave/Imager (SSM/I) algorithms for sea-ice production (Tamura et al., 2016). The model was spun up for 21 model years using 1992-2012 forcing. After spinup, the 1992-2012 forcing was repeated and we analyzed the mean seasonal cycle of melt from the second run. The mean spatial distribution and temporal variability of basal melt are shown in Fig. 5.

The distribution of basal melt at TIS mimics observations of other ice shelves, with the highest melt rates focused near the deep grounding line (e.g., Dutrieux et al., 2013). Seasonal variability is most significant in the inner TIS, where mean melt rates are highest, whereas the shallow ice base of the outer TIS experiences only a weak seasonal cycle superimposed on a low mean melt rate. Everywhere beneath the ice shelf, the basal melt rate reaches a maximum in autumn and a minimum in the spring.

Ice shelf thinning tends to reduce buttressing and allow ice shelf acceleration. Using a simple model developed by Greene et al. (2017a) (adapted from Joughin et al., 2004) to estimate velocity anomalies resulting from seasonal changes in ice thickness, we find that, on subannual timescales, basal melt anomalies should only affect TIS velocity on the order of $1 \mathrm{~m} \mathrm{yr}^{-1}$ (Fig. 5). Note that velocity predictions are negatively correlated with ice thickness, which is calculated from the time integral of basal melt rate anomalies. Accordingly, velocity maxima related to basal melt do not correspond directly to basal melt rate maxima but should occur at the end of the high-melt season in July, when ice thickness reaches a minimum.

Small perturbations in ice shelf thickness have the greatest influence on ice shelf buttressing, where the ice shelf is thin. However, the thick ice of the inner TIS experiences much more seasonal melt variability than the thin ice of the outer TIS, so it is somewhat by coincidence that the large 

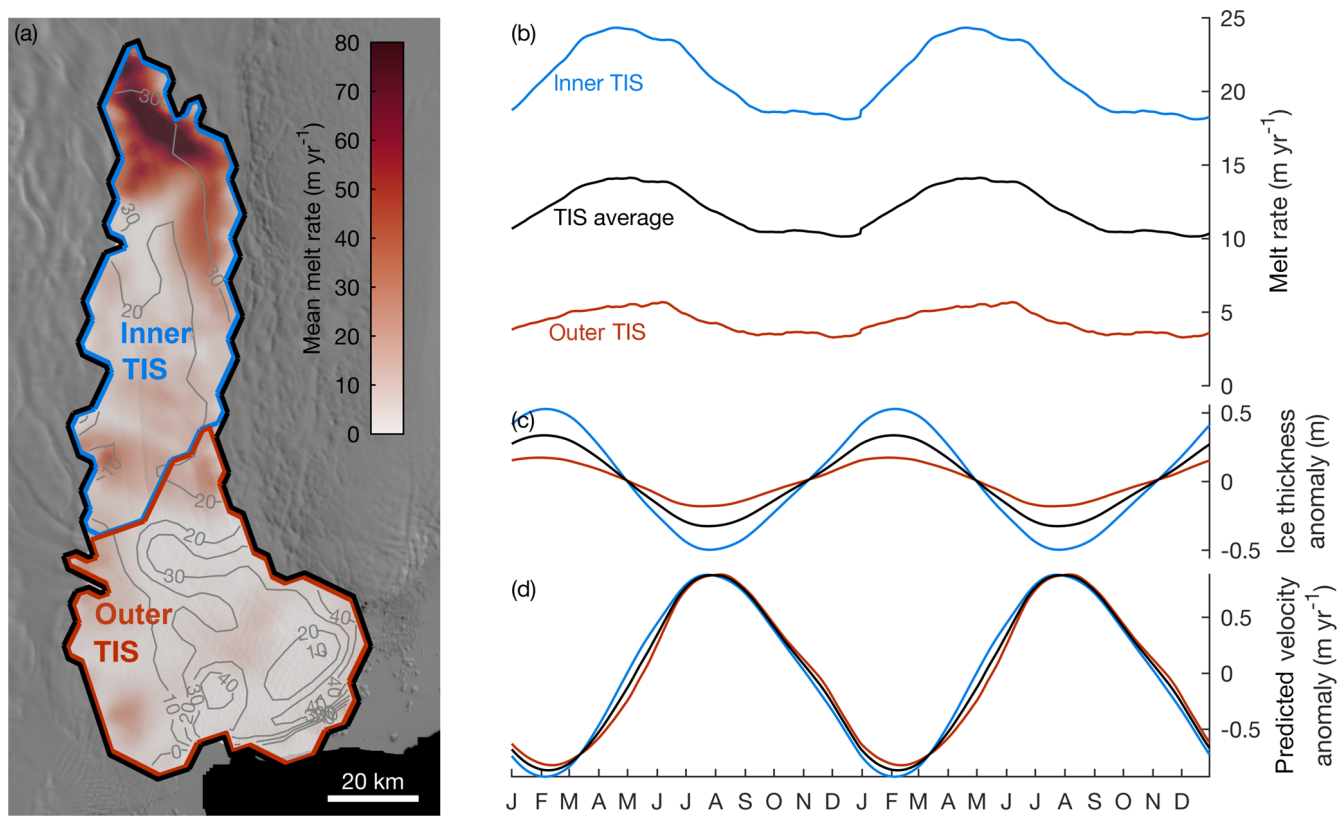

Figure 5. Modeled basal melt. (a) Mean melt rate distribution shows melt focused where the ice shelf base is deepest, exceeding $80 \mathrm{~m} \mathrm{yr}^{-1}$ near the grounding line of the inner TIS. Gray contours show melt rate lag times in days relative to anomalies at the ice front, indicating that melt anomalies propagate in a clockwise fashion around the cavity. (b) Two years of 1992-2012 climatological melt rates averaged within the subdomains in (a). (c) Ice thickness anomalies corresponding to the time integral of melt rate anomalies. (d) Ice velocity anomalies expected to result from seasonal variations in ice shelf thickness.

$\left(>8 \mathrm{~m} \mathrm{yr}^{-1}\right)$ increase in melt rate from spring to autumn beneath the thick $(>2000 \mathrm{~m})$ ice of the inner TIS affects local ice velocity to approximately the same degree as the much smaller $\left(\sim 3 \mathrm{~m} \mathrm{yr}^{-1}\right)$ seasonal melt rate variability in the outer TIS, where ice is much thinner (Fig. 5).

The model we use to estimate melt-induced velocity anomalies assumes TIS velocity is limited only by lateral shear stress at the ice shelf margins and velocity anomalies are purely a function of local ice thickness. These assumptions vastly oversimplify the complex stress regime of the TIS but are used to obtain an order of magnitude approximation of how the TIS should respond to seasonal variability of ice thickness driven by basal melt. From this simple model it is clear that the $<1 \mathrm{~m} \mathrm{yr}^{-1}$ variability expected to result from seasonal basal melt anomalies cannot explain the observed $>100 \mathrm{~m} \mathrm{yr}^{-1}$ seasonal variability of TIS velocity. Moreover, holding other factors are constant, the seasonal cycle of basal melt produces an ice shelf that grows throughout the summer and reaches a maximum thickness in February. Accordingly, basal melt anomalies should result in a summer slowdown and a velocity minimum in February, when observations show TIS nearing its maximum velocity. Thus, it is unlikely that the seasonal cycle of basal melt could explain the observed pattern of spring-to-autumn acceleration of TIS.

\section{Sea ice concentration and thickness}

To assess whether the presence of sea ice may influence the flow of TIS, we analyzed observational data from microwave, thermal, and visual band satellite sensors, along with model data of sea ice thickness near the TIS front. We used daily observations of sea ice concentration (Cavalieri et al., 1996) and generated a time series given by the mean of three $25 \mathrm{~km}$ grid cells located close to the TIS front (shown in Fig. 6). In addition to ice concentration observations, we also analyzed daily effective sea ice thickness from ECCO v4-r3 for the period 2000-2015 (Fukumori et al., 2017). We focused on the time series of sea ice thickness for the grid cell centered on $\left(66.47^{\circ} \mathrm{S}, 116.50^{\circ} \mathrm{E}\right)$, indicated by gold markers in Figs. 1 and 6 . To fully understand the spatial and temporal variability of sea ice, we also inspected 315 cloud-free MODIS visual (band 2) and 164 thermal (band 32) images acquired throughout the year by the Aqua and Terra platforms between 2000 and 2017 (Scambos et al., 2001; Greene and Blankenship, 2018).

Figure 6 shows the seasonal cycle of sea ice growth and decay. The minimum ice concentration typically occurs at the TIS front in mid-March, followed by increasing ice concentration throughout autumn as air temperatures decline (Dee et al., 2011). Inspection of visual and thermal band images reveals that sea ice consolidates and fastens to the western TIS in early to mid-May. The rigid connection of landfast ice to the TIS front holds throughout the winter, with the ex- 


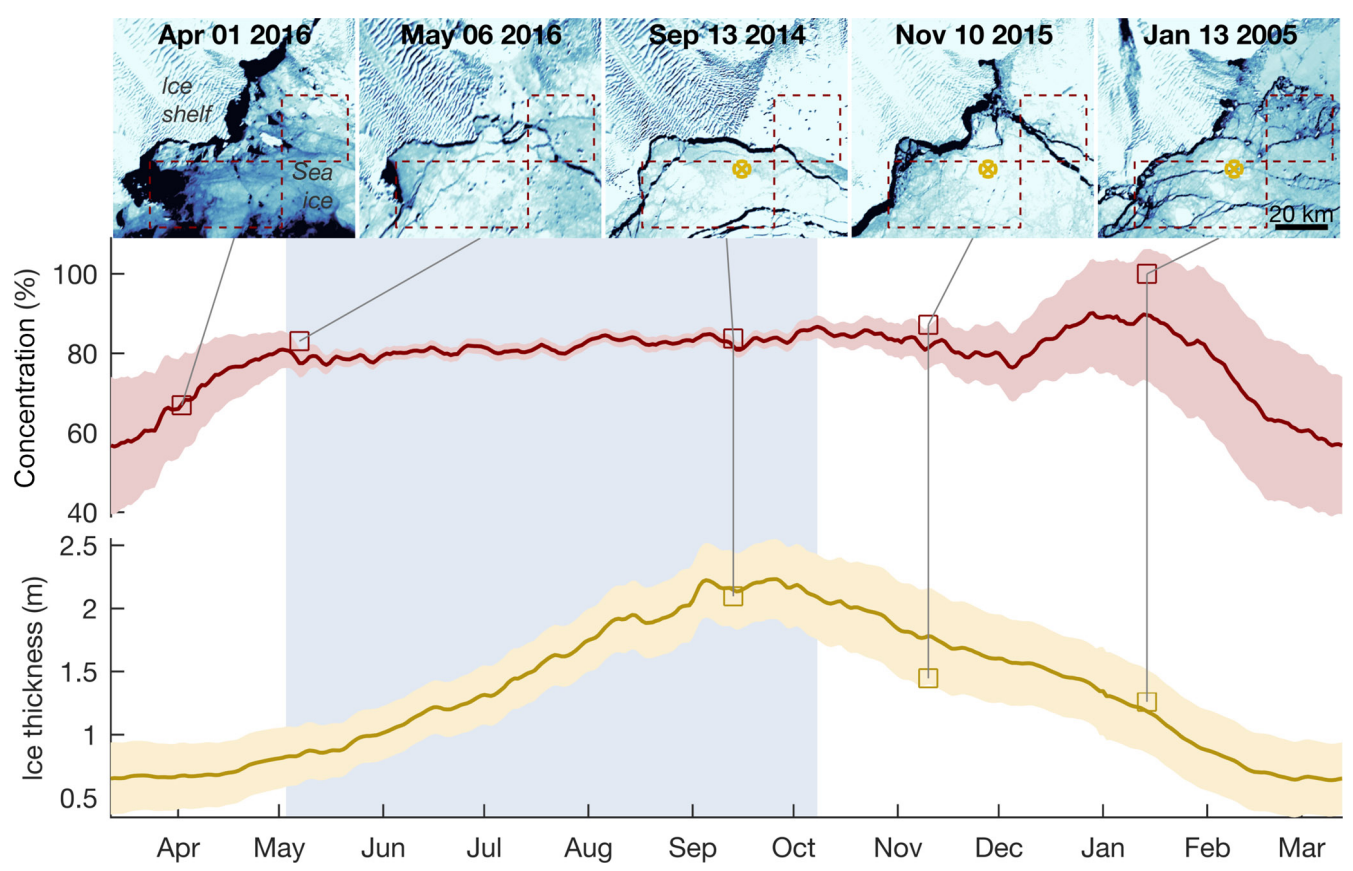

Figure 6. Seasonal cycle of sea ice at the TIS front. MODIS visual band imagery (Scambos et al., 2001), remotely sensed ice concentration (Cavalieri et al., 1996), and ECCO v4-r3 effective sea ice thickness (Fukumori et al., 2017) reveal a seasonal cycle of sea ice growth and decay beginning around 12 March each year, when sea ice concentration is at minimum. Ice concentration and thickness time series are shown with shading indicating daily values of $\pm 1 \sigma$. Light blue background shading indicates the presence of fast ice at the TIS front, from about 3 May to 8 October. During this winter period, remotely sensed ice concentration values remain relatively constant despite continued growth of sea ice. Average sea ice thickness steadily declines throughout the summer, while thin, unconsolidated sea ice often temporarily fills the area and is detected by remote sensors. Five example MODIS images (Scambos et al., 2001) show sea ice fastened to half of the TIS front in May and September, with dashed quadrangles indicating the region of ice concentration averaging and a gold marker denotes the location of the ECCO sea ice thickness time series (not shown for 2016, when no ECCO v4-r3 data are available).

ception of a small polynya abutting Law Dome that briefly opened in July 2016 (see Alley et al., 2016). Regardless of polynya activity, the majority of landfast ice remains connected to the TIS front, and each year the landfast connection breaks in October or early November, followed by a visible reduction in sea ice cover that occurs throughout November. In some years, sea ice concentration continues to decline throughout the summer, but more commonly, the region temporarily fills with unconsolidated ice, causing sea ice concentration to peak in January (Greene, 2017). From January to March, sea ice melts or is exported away from the TIS front until concentration reaches a minimum in mid-March, then the cycle repeats. Sea ice thickness data are more well behaved, generally waxing and waning monotonically between a minimum in late March and maximum in late September. In this way, sea ice thickness follows the broader climatology reported by Fraser et al. (2012), who found that landfast ice between 90 and $160^{\circ} \mathrm{E}$ grows from a minimum extent in March to a maximum in late September or early October.

We suspect that sea ice concentration is a poor measure of ice strength, because the simple fraction of a grid cell's surface area covered by ice offers no indication of ice thickness or level of consolidation. This is seen not only in the sum- mer melt season, during which sea ice concentration often increases, but also in winter, when ice concentration observations remain constant while the ice grows steadily thicker. We posit that sea ice thickness is a better proxy for sea ice strength because the ECCO v4-r3 model was indirectly constrained by observations of sea ice concentration but also accounts for winter sea ice growth.

\section{Discussion}

\subsection{Causes of seasonal variability}

Studies of floating and marine-terminating glaciers around the world have found a diverse set of causes of seasonal velocity variability, suggesting that local phenomena control glacier flow on subannual timescales, and there is no single dominating global cause of seasonal variability. In some regions of Greenland, neighboring glaciers behave differently based on the mechanisms that control them, and those mechanisms can change for a given glacier throughout the year (Howat et al., 2010; Moon et al., 2014).

On grounded ice, seasonal velocity variability often results from surface water draining to the bed, where it can tem- 


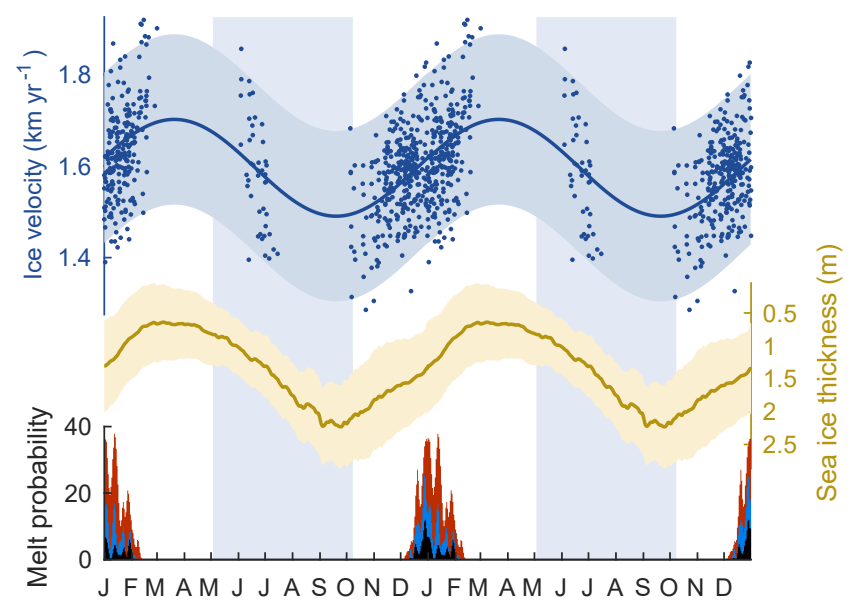

Figure 7. Causes of springtime acceleration. Time series of MODIS-derived ice velocity $\pm 2 \sigma$ shaded, ECCO v4-r3 sea ice thickness $\pm 2 \sigma$ shaded, and melt probability repeated from Figs. 3, 4 , and 6 . Note the inverted axis of the sea ice thickness time series. Characteristic springtime acceleration near the TIS front begins with the breakup of landfast sea ice and is possibly enhanced later in the year by shear margin weakening resulting from surface melt. Vertical shaded blue areas indicate typical times of landfast ice connection with TIS. Two years of the mean cycle are shown for visual continuity. Velocity anomalies predicted from basal melt are not shown here because the $\pm 1 \mathrm{~m} \mathrm{yr}^{-1}$ amplitude would visually indiscernible at the observed scale of interannual velocity variability.

porarily pressurize an inefficient hydrological system, allowing the overlying ice to accelerate until an efficient drainage system forms or the water otherwise evacuates (Zwally et al., 2002; Parizek and Alley, 2004; Bartholomew et al., 2010). At Totten Glacier, we detect very little seasonal velocity variability on grounded ice, and the onset of acceleration we observe on the floating ice shelf begins well before surface water is detected anywhere in the region (Fig. 7). We therefore rule out the possibility that surface melt is responsible for initiating TIS acceleration each year.

On multiyear timescales, basal melt can lead to ice shelf acceleration as thinning reduces the internal buttressing strength of ice (Christianson et al., 2016; Greene et al., 2017a). However, neither the timing nor the amplitude of melt-induced thinning can account for the seasonal velocity variability we observe at TIS. We find a small seasonal cycle of ice shelf thickness due to variable basal melt throughout the year, but the corresponding velocity anomalies should be 2 orders of magnitude smaller than the observed velocity anomalies. Roberts et al. (2017) pointed out that at TIS, a mechanism exists that can amplify the effects of basal melt on ice velocity: ice rumples in the middle of TIS may provide decreasing resistance to flow as the ice shelf thins, so it is possible that the simple model of ice shelf buttressing we employ in Sect. 4 underestimates the effects of basal melt on TIS velocity. Nonetheless, we find that basal melt is still incapable of causing the observed seasonal velocity cycle because ice shelf thickness maxima occur each year nearly coincident in time with observed velocity maxima.

In the GoLIVE data set and in MODIS-derived velocities, we find that the outer TIS accelerates each year between spring and autumn. The spatial pattern of the annual acceleration suggests that the flow of ice is governed by processes at the ice front (Fig. 1), and the timing of the acceleration implicates the annual breakup of landfast ice at the TIS front as an influencing factor. Figure 7 shows the relationship between sea ice thickness, surface melt, and TIS velocity. The temporal and spatial resolution of data available at TIS limit our ability to investigate the specific processes by which the presence of sea ice may slow the flow of TIS, but similar studies elsewhere have found that back stress from ice mélange (Walter et al., 2012; Todd and Christoffersen, 2014; Otero et al., 2017) can stabilize the ice front and reduce or entirely shut down calving over winter (Sohn et al., 1998; Reeh et al., 2001; Amundson et al., 2010; Moon et al., 2015; Robel, 2017), thus preserving internal stresses in the glacier and slowing its flow (Krug et al., 2015). The pattern of TIS acceleration we observe is similar to seasonal velocity anomalies observed at other marine-terminating glaciers and ice shelves, where the annual breakup of sea ice causes velocity anomalies that are seen up to tens of kilometers from the glacier terminus (Nakamura et al., 2010; Walter et al., 2012; Zhou et al., 2014).

We find that the outer TIS accelerates each year, likely in response to lost buttressing upon the breakup of rigid sea ice at the ice shelf terminus. The response we observe is consistent with other studies that have shown a seasonal pattern of ice front calving and glacier acceleration in response to the disintegration of rigid sea ice caused by warm sea surface temperatures (Howat et al., 2010; Cassotto et al., 2015; Luckman et al., 2015). Ice front processes are likely responsible for the onset of TIS acceleration each spring, but we cannot rule out the possibility that other factors may influence the flow of TIS in other parts of the year. It is possible that onset of acceleration begins with the breakup of sea ice at the TIS front, but surface melt could play a role later in the summer or autumn if water percolates into the ice and weakens the shear margins.

In Figs. 3 and 7 we approximate the seasonal velocity variability of TIS as a sinusoid. The seasonal flow of TIS is likely more complex, and the timing and magnitude of spring-to-autumn speedup presumably vary from year to year. Nonetheless, we have shown that TIS responds to local forcing on subannual timescales, the response is observable, and it correlates with the breakup of sea ice at the glacier terminus each spring. 


\subsection{Impacts of seasonal variability on measurements of long-term change}

We find that TIS accelerates each year from spring to autumn, and this seasonal variability has the potential to contaminate estimates of annual mass flux and interannual variability. Most common methods of measuring ice velocity rely upon subannual displacement measurements to characterize annual ice flux (e.g., Mouginot et al., 2017a), but where ice velocity varies throughout the year, short-term measurements can be aliased by the natural seasonal cycle and provide an inaccurate measure of annual ice flux. The seasonal variability we observe at TIS suggests that measurements acquired in the spring likely underestimate the mean annual velocity of the ice shelf, and autumn measurements overestimate them.

The most significant seasonal variability at TIS is found near the ice front, where spring and autumn velocities can differ by up to $10 \%$. Although this represents a small modulation of the mean flow, it is on the order of interannual variability that has previously been attributed to interannual changes in ocean forcing, and the pattern of summer acceleration we show in Fig. 1 bears a notable resemblance to accelerations that have previously been reported as evidence of long-term change (Li et al., 2016). Although direct investigations of interannual change are beyond the scope of this study, we can consider how seasonal variability may have influenced previous studies of TIS velocity.

Velocity variability at TIS has been investigated in three recent papers that tracked ice accelerations and slowdowns over the past few decades, and each study found that on interannual timescales, TIS dynamically responds to ocean forcing from below. We do not find any evidence that contradicts the overall findings of the previous studies, but in some cases, velocities were measured over periods of less than 1 year, and may have been aliased by seasonal variability. Roberts et al. (2017) and Greene et al. (2017a) each measured displacements between images separated by near-integer multiples of years. By this method, it is unlikely that they inadvertently captured subannual variability, unless the timing of acceleration events occurred out of sync with the calendar year. Such is likely the case for the 2009 to 2010 acceleration observed by $\mathrm{Li}$ et al. (2016), who compared velocity measurements obtained between September and January of both years. Although the periods of observation were roughly the same in both years, the spring breakup of fast ice did not occur until after the start of observations in 2009, whereas the spring breakup was already underway when observations began in 2010 , and the TIS had already begun to respond. The velocity difference between the 2009 and 2010 measurements shows acceleration focused at the ice shelf terminus, and this likely reflects a difference in timing of the seasonal cycle that may not be associated with any difference in mean annual velocities. The inconsistent timing of fast ice breakup each year suggests that assessments of interannual change made from short-term displacement measurements can be contaminated by seasonal effects, even if observations are taken at the same time each year.

Despite the seasonal variability we observe near the TIS front, the mass balance of an ice sheet is more meaningfully measured at the grounding line, where ice begins to have an impact on sea level. Our results show little subannual velocity variability at the grounding line, thus supporting the grounding line flux estimates by $\mathrm{Li}$ et al. (2016).

\subsection{Sea ice influence on ice sheet mass balance}

The GoLIVE and MODIS velocity measurements show that TIS is sensitive to environmental forcing on subannual timescales, and its flow is primarily controlled by the presence of sea ice at the TIS front. This finding warrants consideration of how changes in sea ice could affect the stability of the TIS and the long-term mass balance of the Aurora Subglacial Basin. Elsewhere in Antarctica, loss of multiyear landfast ice has led to major calving events and glacier acceleration (Khazendar et al., 2009; Miles et al., 2017; Aoki, 2017). The landfast ice we observe is not multiyear ice, and is thus unlikely to be associated with any catastrophic events at TIS in the near future. However, calving front processes can have far-reaching effects on glacier thickness and velocity (Nick et al., 2009), and it is possible that long-term changes in winter sea ice cover (Bracegirdle et al., 2008) could have integrated effects on TIS buttressing: if the duration and thickness of winter sea ice control the total annual buttressing at the ice shelf front, long-term changes in sea ice cover could affect the annual flow of TIS and potentially the mass balance of TIS and the Aurora Subglacial Basin.

\section{Conclusions}

We find that TIS has a characteristic seasonal velocity profile, which could lead to inaccurate estimates of the annual mass balance of TIS and may have aliased some previous measurements of interannual variability. Annual ice velocity maps are now available, covering most of Antarctica (Mouginot et al., 2017c), but interpreting such data sets at TIS and elsewhere requires an understanding of where ice velocity varies seasonally and by how much. Our results provide context for how and where such velocity mosaics may be used to interpret interannual change at Totten Glacier.

Previous studies have linked interannual velocity variability at TIS to periods of ice shelf thickening and thinning caused by sustained basal melt rate anomalies. On subannual timescales, however, the seasonal amplitude of basal melt variability is insufficient to produce enough thinning to elicit an observable velocity response. Furthermore, seasonal basal melt anomalies result in an ice shelf that is the thinnest, weakest, and should flow the fastest in winter, when our observations show the TIS reaches its minimum velocity. 
In accord with other studies of ice shelves and glaciers around Antarctica and Greenland, we find that the seasonal variability of TIS velocity is most closely linked to the presence of sea ice at the ice shelf front. Each spring when surface waters warm, rigid landfast ice breaks its connection to the TIS front, the calving rate increases, and the TIS responds by accelerating by nearly $10 \%$ close the ice shelf terminus. Velocity anomalies are most significant over floating ice, and spring acceleration precedes surface melt each year, suggesting that subglacial hydrology does not cause the seasonal cycle of TIS velocity we observe.

We find that winter sea ice is a primary contributor to the seasonal variability of the outer TIS velocity. If the future brings long-term changes in the thickness or extent of winter sea ice, the integrated effects of changes in buttressing could manifest as long-term changes in the mass balance of TIS and the Aurora Subglacial Basin.
Code and data availability. GoLIVE data (Scambos et al., 2016; Fahnestock et al., 2016) are available at https: //nsidc.org/data/NSIDC-0710 (last access: 15 April 2018). MODIS images (Scambos et al., 2001) used in this study were obtained from ftp://sidads.colorado.edu/pub/DATASETS/ICESHELVES (last access: 15 April 2018). The ImGRAFT template matching software (Messerli and Grinsted, 2015) is available at http://imgraft.glaciology.net (last access: 15 April 2018). The melting-1979-2017-v2.nc surface melt data from Picard and Fily (2006) are available at http://pp.ige-grenoble. fr/pageperso/picardgh/melting/ (last access: 15 April 2018). ECCO v4-r3 sea ice effective thickness data can be found at ftp://ecco.jpl.nasa.gov/Version4/Release3/nctiles_daily/SIheff (last access: 15 April 2018). The analysis was performed with Antarctic Mapping Tools for Matlab (Greene et al., 2017b). The background image in Figs. 1, 4, and 5 is the MODIS Mosaic of Antarctica (Haran et al., 2014). Figures 1, 4, 5, and 6 use cmocean color maps (Thyng et al., 2016). 


\section{Appendix A: Uncertainty quantification}

To verify the presence of seasonal variation in ice flow speed, we performed a $p$ test using the null hypothesis that the amplitude of seasonal variability is $0 \mathrm{myr}^{-1}$. The 565 MODIS velocity measurements match the sinusoid fit by least squares with a Pearson correlation coefficient of $r=0.472$ and a corresponding $t_{\text {statistic }}=12.70$. The probability of the null hypothesis that there is no seasonal cycle is $p=6 \times 10^{-33}$, and thus we reject it in favor of the alternate hypothesis that cyclic seasonal behavior is present at TIS.

We used a bootstrapping technique to estimate uncertainty in the characteristic sinusoid fit to the MODIS velocity data. Figure A1 shows the phases and amplitudes of sinusoids fit by least squares to 10000 random resamplings of the MODIS velocity data set. The mean amplitude of the sinusoid is $106 \mathrm{~m} \mathrm{yr}^{-1}$ with a $1 \sigma$ uncertainty of $9.1 \mathrm{~m} \mathrm{yr}^{-1}$. The phase of the sinusoid is characterized by a maximum velocity on 21 March (and corresponding minimum 19 September) with a $1 \sigma$ uncertainty of 4.9 days. The root mean square of the measurement residuals is $92.6 \pm 2.9 \mathrm{~m} \mathrm{yr}^{-1}$ and reflects a combination of the measurement error, interannual variability in amplitude and timing of acceleration or slowdown, and the difference between true seasonal variability and the sinusoid approximation.

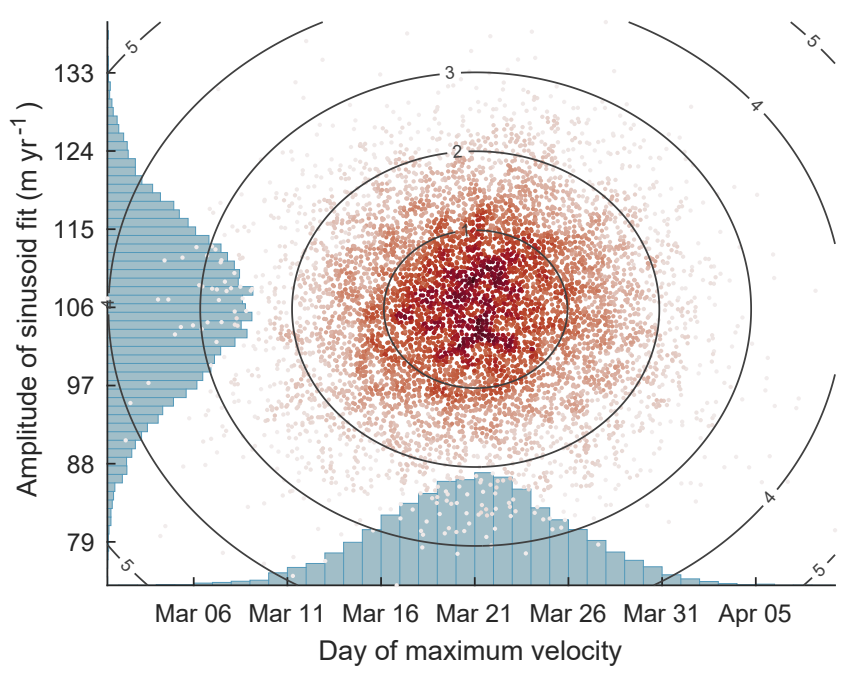

Figure A1. Bootstrap distributions of sinusoid parameters. Scattered data show the phase and amplitudes of sinusoids fit by least squares to 10000 random samples of MODIS velocity measurements. Red indicates the local density of the scattered data. Histograms show the distributions of each parameter. Contour lines and axis tick marks indicate 1 standard deviation intervals for each parameter. 
Author contributions. CAG conceived of this study, generated the figures, and wrote the manuscript. Analysis was conducted by CAG under the direction of DDB, with guidance from DAY. DEG and BKGF developed the ice-ocean model described in Sect. 4 and assisted in interpreting its results.

Competing interests. The authors declare that they have no conflicts of interest.

Acknowledgements. We thank Mason J. Fried and Denis Felikson for many helpful discussions throughout the development of this work. We also thank Alex S. Gardner and the anonymous reviewer for providing feedback and suggestions that significantly improved the paper. This work was supported by the G. Unger Vetlesen Foundation and NSF grant PLR-1543452. Ocean modeling research was supported by the Australian Government's Cooperative Research Centre Programme through the Antarctic Climate \& Ecosystems Cooperative Research Centre, the Australian Research Council's Special Research Initiative for Antarctic Gateway Partnership (Project ID SR140300001) and computing resource grants $m 68$, gh9 and $n k l$ from the Australian Government National Computing Infrastructure. This is UTIG contribution 3280.

Edited by: Kenny Matsuoka

Reviewed by: Alex Gardner and one anonymous referee

\section{References}

Alley, K. E., Scambos, T. A., Siegfried, M. R., and Fricker, H. A.: Impacts of warm water on Antarctic ice shelf stability through basal channel formation, Nat. Geosci., 9, 290-293, https://doi.org/10.1038/ngeo2675, 2016.

Amundson, J. M., Fahnestock, M., Truffer, M., Brown, J., Lüthi, M. P., and Motyka, R. J.: Ice mélange dynamics and implications for terminus stability, Jakobshavn Isbræ, Greenland, J. Geophys. Res.-Earth, 115, F01005, https://doi.org/10.1029/2009JF001405, 2010.

Andrews, L. C., Catania, G. A., Hoffman, M. J., Gulley, J. D., Lüthi, M. P., Ryser, C., Hawley, R. L., and Neumann, T. A.: Direct observations of evolving subglacial drainage beneath the Greenland Ice Sheet, Nature, 514, 80-83, https://doi.org/10.1038/nature13796, 2014.

Aoki, S.: Breakup of land-fast sea ice in Lützow-Holm Bay, East Antarctica, and its teleconnection to tropical Pacific sea surface temperatures, Geophys. Res. Lett., 44, 3219-3227, https://doi.org/10.1002/2017GL072835, 2017.

Bartholomew, I., Nienow, P., Mair, D., Hubbard, A., King, M. A., and Sole, A.: Seasonal evolution of subglacial drainage and acceleration in a Greenland outlet glacier, Nat. Geosci., 3, 408-411, https://doi.org/10.1038/ngeo863, 2010.

Bracegirdle, T. J., Connolley, W. M., and Turner, J.: Antarctic climate change over the twenty first century, J. Geophys. Res.Atmos., 113, D03103, https://doi.org/10.1029/2007JD008933, 2008.

Cassotto, R., Fahnestock, M., Amundson, J. M., Truffer, M., and Joughin, I.: Seasonal and interannual varia- tions in ice melange and its impact on terminus stability, Jakobshavn Isbræ, Greenland, J. Glaciol., 61, 76-88, https://doi.org/10.3189/2015JoG13J235, 2015.

Cavalieri, D., Parkinson, C., Gloersen, P., and Zwally, H. J.: Sea Ice Concentrations from Nimbus-7 SMMR and DMSP SSM/I-SSMIS Passive Microwave Data, Version 1, https://doi.org/10.5067/8GQ8LZQVL0VL, 1996.

Cavanagh, J., Lampkin, D., and Moon, T.: Seasonal variability in regional ice flow due to meltwater injection into the shear margins of Jakobshavn Isbræ, J. Geophys. Res.-Earth, 122, 2488-2505, https://doi.org/10.1002/2016JF004187, 2017.

Chen, J., Wilson, C., Blankenship, D., and Tapley, B.: Accelerated Antarctic ice loss from satellite gravity measurements, Nat. Geosci., 2, 859-862, https://doi.org/10.1038/ngeo694, 2009.

Christianson, K., Bushuk, M., Dutrieux, P., Parizek, B. R., Joughin, I. R., Alley, R. B., Shean, D. E., Abrahamsen, E. P., Anandakrishnan, S., Heywood, K. J., and Kim, T. W.: Sensitivity of Pine Island Glacier to observed ocean forcing, Geophys. Res. Lett., 43, 817-825, https://doi.org/10.1002/2016GL070500, 2016.

Dee, D. P., Uppala, S. M., Simmons, A. J., Berrisford, P., Poli, P., Kobayashi, S., Andrae, U., Balmaseda, M. A., Balsamo, G., Bauer, P., Bechtold, P., Beljaars, A. C. M., van de Berg, L., Bidlot, J., Bormann, N., Delsol, C., Dragani, R., Fuentes, M., Geer, A. J., Haimberger, L., Healy, S. B., Hersbach, H., Hólm, E. V., Isaksen, L., Kållberg, P., Köhler, M., Matricardi, M., McNally, A. P., Monge-Sanz, B. M., Morcrette, J.-J., Park, B.-K., Peubey, C., de Rosnay, P., Tavolato, C., Thépaut, J.-N., and Vitart, F.: The ERA-Interim reanalysis: configuration and performance of the data assimilation system, Q. J. Roy. Meteor. Soc., 137, 553-597, https://doi.org/10.1002/qj.828, 2011.

Dinniman, M. S., Klinck, J. M., and Smith, W. O.: Cross-shelf exchange in a model of the Ross Sea circulation and biogeochemistry, Deep-Sea Res. Pt. II, 50, 3103-3120, 2003.

Dutrieux, P., Vaughan, D. G., Corr, H. F. J., Jenkins, A., Holland, P. R., Joughin, I., and Fleming, A. H.: Pine Island glacier ice shelf melt distributed at kilometre scales, The Cryosphere, 7, 15431555, https://doi.org/10.5194/tc-7-1543-2013, 2013.

Fahnestock, M., Scambos, T., Moon, T., Gardner, A., Haran, T., and Klinger, M.: Rapid large-area mapping of ice flow using Landsat 8, Remote Sens. Environ., 185, 84-94, https://doi.org/10.1016/j.rse.2015.11.023, 2016.

Fraser, A. D., Massom, R. A., Michael, K. J., Galton-Fenzi, B. K., and Lieser, J. L.: East Antarctic landfast sea ice distribution and variability, 2000-08, J. Climate, 25, 1137-1156, https://doi.org/10.1175/JCLI-D-10-05032.1, 2012.

Fricker, H. A., Popov, S., Allison, I., and Young, N.: Distribution of marine ice beneath the Amery Ice Shelf, Geophys. Res. Lett., 28 , 2241-2244, https://doi.org/10.1029/2000GL012461, 2001.

Fukumori, I., Wang, O., Fenty, I., Forget, G., Heimbach, P., and Ponte, R. M.: ECCO Version 4 Release 3, available at: http://hdl handle.net/1721.1/110380, https://doi.org/1721.1/110380, 2017.

Galton-Fenzi, B., Hunter, J., Coleman, R., Marsland, S., and Warner, R.: Modeling the basal melting and marine ice accretion of the Amery Ice Shelf, J. Geophys. Res.-Oceans, 117, C09031, https://doi.org/10.1029/2012JC008214, 2012.

Greenbaum, J., Blankenship, D., Young, D., Richter, T., Roberts, J., Aitken, A., Legresy, B., Schroeder, D., Warner, R., Van Ommen, T., and Siegert, M. J.: Ocean access to a cavity beneath 
Totten Glacier in East Antarctica, Nat. Geosci., 8, 294-298, https://doi.org/10.1038/ngeo2388, 2015.

Greene, C. A.: Drivers of change in East Antarctic ice shelves, PhD thesis, The University of Texas at Austin, 2017.

Greene, C. A. and Blankenship, D. D.: A Method of Repeat Photoclinometry for Detecting Kilometer-Scale Ice Sheet Surface Evolution, IEEE T. Geosci. Remote, 56, 2074-2082, https://doi.org/10.1109/TGRS.2017.2773364, 2018.

Greene, C. A., Blankenship, D. D., Gwyther, D. E., Silvano, A., and van Wijk, E.: Wind causes Totten Ice Shelf melt and acceleration, Science Advances, 3, e1701681, https://doi.org/10.1126/sciadv.1701681, 2017a.

Greene, C. A., Gwyther, D. E., and Blankenship, D. D.: Antarctic Mapping Tools for MATLAB, Comput. Geosci., 104, 151-157, https://doi.org/10.1016/j.cageo.2016.08.003, 2017b.

Gwyther, D. E., Galton-Fenzi, B. K., Hunter, J. R., and Roberts, J. L.: Simulated melt rates for the Totten and Dalton ice shelves, Ocean Sci., 10, 267-279, https://doi.org/10.5194/os-10267-2014, 2014.

Haran, T., Bohlander, J., Scambos, T., Painter, T., and Fahnestock, M.: MODIS Mosaic of Antarctica 2008-2009 (MOA2009) Image Map, Version 1, NSIDC National Snow and Ice Data Center, https://doi.org/10.7265/N5KP8037, 2014.

Howat, I. M., Box, J. E., Ahn, Y., Herrington, A., and McFadden, E. M.: Seasonal variability in the dynamics of marineterminating outlet glaciers in Greenland, J. Glaciol., 56, 601613,2010

Hulbe, C. L., Johnston, R., Joughin, I., and Scambos, T.: Marine ice modification of fringing ice shelf flow, Arct. Antarct. Alp. Res., 37, 323-330, 2005.

Joughin, I., MacAyeal, D. R., and Tulaczyk, S.: Basal shear stress of the Ross ice streams from control method inversions, J. Geophys. Res.-Sol. Ea., 109, B09405, https://doi.org/10.1029/2003JB002960, 2004.

Joughin, I., Das, S. B., King, M. A., Smith, B. E., Howat, I. M., and Moon, T.: Seasonal speedup along the western flank of the Greenland Ice Sheet, Science, 320, 781-783, 2008.

Khazendar, A., Rignot, E., and Larour, E.: Roles of marine ice, rheology, and fracture in the flow and stability of the Brunt/Stancomb-Wills Ice Shelf, J. Geophys. Res.-Earth, 114, F04007, https://doi.org/10.1029/2008JF001124, 2009.

Krug, J., Durand, G., Gagliardini, O., and Weiss, J.: Modelling the impact of submarine frontal melting and ice mélange on glacier dynamics, The Cryosphere, 9, 989-1003, https://doi.org/10.5194/tc-9-989-2015, 2015.

Li, X., Rignot, E., Mouginot, J., and Scheuchl, B.: Ice flow dynamics and mass loss of Totten Glacier, East Antarctica, from 1989 to 2015, Geophys. Res. Lett., 43, 6366-6373, https://doi.org/10.1002/2016GL069173, 2016.

Liu, H. and Miller, K.: Fracture toughness of fresh-water ice, J. Glaciol., 22, 135-143, 1979.

Luckman, A., Benn, D. I., Cottier, F., Bevan, S., Nilsen, F., and Inall, M.: Calving rates at tidewater glaciers vary strongly with ocean temperature, Nat. Commun., 6, 8566, https://doi.org/10.1038/ncomms9566, 2015.

Massom, R. A., Giles, A. B., Fricker, H. A., Warner, R. C., Legrésy, B., Hyland, G., Young, N., and Fraser, A. D.: Examining the interaction between multi-year landfast sea ice and the Mertz Glacier Tongue, East Antarctica: Another factor in ice sheet stability?, J. Geophys. Res.-Oceans, 115, C12027, https://doi.org/10.1029/2009JC006083, 2010.

Massom, R. A., Giles, A. B., Warner, R. C., Fricker, H. A., Legrésy, B., Hyland, G., Lescarmontier, L., and Young, N.: External influences on the Mertz Glacier Tongue (East Antarctica) in the decade leading up to its calving in 2010, J. Geophys. Res.-Earth, 120, 490-506, 2015.

Massom, R. A., Scambos, T. A., Bennetts, L. G., Reid, P., Squire, V. A., and Stammerjohn, S. E.: Antarctic ice shelf disintegration triggered by sea ice loss and ocean swell, Nature, 558, 383-389, https://doi.org/10.1038/s41586-018-0212-1, 2018.

Menemenlis, D., Campin, J.-M., Heimbach, P., Hill, C., Lee, T., Nguyen, A., Schodlok, M., and Zhang, H.: ECCO2: High resolution global ocean and sea ice data synthesis, Mercator Ocean Quarterly Newsletter, 31, 13-21, 2008.

Messerli, A. and Grinsted, A.: Image georectification and feature tracking toolbox: ImGRAFT, Geosci. Instrum. Method. Data Syst., 4, 23-34, https://doi.org/10.5194/gi-4-23-2015, 2015.

Miles, B. W., Stokes, C. R., and Jamieson, S. S.: Pan-ice-sheet glacier terminus change in East Antarctica reveals sensitivity of Wilkes Land to sea-ice changes, Science Advances, 2, e1501350, https://doi.org/10.1126/sciadv.1501350, 2016.

Miles, B. W. J., Stokes, C. R., and Jamieson, S. S. R.: Simultaneous disintegration of outlet glaciers in Porpoise Bay (Wilkes Land), East Antarctica, driven by sea ice break-up, The Cryosphere, 11, 427-442, https://doi.org/10.5194/tc-11-427-2017, 2017.

Moon, T., Joughin, I., Smith, B., Broeke, M. R., Berg, W. J., Noël, B., and Usher, M.: Distinct patterns of seasonal Greenland glacier velocity, Geophys. Res. Lett., 41, 7209-7216, https://doi.org/10.1002/2014GL061836, 2014.

Moon, T., Joughin, I., and Smith, B.: Seasonal to multiyear variability of glacier surface velocity, terminus position, and sea ice/ice mélange in northwest Greenland, J. Geophys. Res.-Earth, 120, 818-833, https://doi.org/10.1002/2015JF003494, 2015.

Mouginot, J., Rignot, E., Scheuchl, B., and Millan, R.: Comprehensive Annual Ice Sheet Velocity Mapping Using Landsat8, Sentinel-1, and RADARSAT-2 Data, Remote Sens.-Basel, 9, 364, https://doi.org/10.3390/rs9040364, 2017a.

Mouginot, J., Scheuchl, B., and Rignot, E.: MEaSUREs Antarctic Boundaries for IPY 2007-2009 from Satellite Radar, Version 2, NASA National Snow and Ice Data Center Distributed Active Archive Center, https://doi.org/10.5067/AXE4121732AD, 2017b.

Mouginot, J., Scheuchl, B., and Rignot, E.: MEaSUREs Annual Antarctic Ice Velocity Maps 2005-2016, Version 1, https://doi.org/10.5067/9T4EPQXTJYW9, 2017c.

Nakamura, K., Doi, K., and Shibuya, K.: Fluctuations in the flow velocity of the Antarctic Shirase Glacier over an 11-year period, Polar Sci., 4, 443-455, https://doi.org/10.1016/j.polar.2010.04.010, 2010.

Nick, F. M., Vieli, A., Howat, I. M., and Joughin, I.: Large-scale changes in Greenland outlet glacier dynamics triggered at the terminus, Nat. Geosci., 2, 110-114, https://doi.org/10.1038/ngeo394, 2009.

Otero, J., Navarro, F. J., Lapazaran, J. J., Welty, E., Puczko, D., and Finkelnburg, R.: Modeling the Controls on the Front Position of a Tidewater Glacier in Svalbard, Front. Earth Sci., 5, 29, https://doi.org/10.3389/feart.2017.00029, 2017. 
Paolo, F. S., Fricker, H. A., and Padman, L.: Volume loss from Antarctic ice shelves is accelerating, Science, 348, 327-331, https://doi.org/10.1126/science.aaa0940, 2015.

Parizek, B. R. and Alley, R. B.: Implications of increased Greenland surface melt under global-warming scenarios: icesheet simulations, Quaternary Sci. Rev., 23, 1013-1027, https://doi.org/10.1016/j.quascirev.2003.12.024, 2004.

Picard, G. and Fily, M.: Surface melting observations in Antarctica by microwave radiometers: Correcting 26-year time series from changes in acquisition hours, Remote Sens. Environ., 104, 325336, 2006

Pritchard, H., Ligtenberg, S., Fricker, H., Vaughan, D., Van den Broeke, M., and Padman, L.: Antarctic ice-sheet loss driven by basal melting of ice shelves, Nature, 484, 502-505, https://doi.org/10.1038/nature10968, 2012.

Pritchard, H. D., Arthern, R. J., Vaughan, D. G., and Edwards, L. A.: Extensive dynamic thinning on the margins of the Greenland and Antarctic ice sheets, Nature, 461, 971-975, https://doi.org/10.1038/nature08471, 2009.

Reeh, N., Thomsen, H. H., Higgins, A. K., and Weidick, A.: Sea ice and the stability of north and northeast Greenland floating glaciers, Ann. Glaciol., 33, 474-480, https://doi.org/10.3189/172756401781818554, 2001.

Rignot, E., Mouginot, J., and Scheuchl, B.: MEaSUREs InSAR-Based Antarctica Ice Velocity Map, https://doi.org/10.5067/MEASURES/CRYOSPHERE/nsidc0484.001, 2011.

Rignot, E., Jacobs, S., Mouginot, J., and Scheuchl, B.: Iceshelf melting around Antarctica, Science, 341, 266-270, https://doi.org/10.1126/science.1235798, 2013.

Rignot, E., Mouginot, J., and Scheuchl, B.: MEaSUREs InSAR-Based Antarctica Ice Velocity Map, Version 2, https://doi.org/10.5067/D7GK8F5J8M8R, 2017.

Robel, A. A.: Thinning sea ice weakens buttressing force of iceberg mélange and promotes calving, Nat. Commun., 8, 14596, https://doi.org/10.1038/ncomms14596, 2017.

Roberts, J. L., Warner, R. C., Young, D., Wright, A., van Ommen, T. D., Blankenship, D. D., Siegert, M., Young, N. W., Tabacco, I. E., Forieri, A., Passerini, A., Zirizzotti, A., and Frezzotti, M.: Refined broad-scale sub-glacial morphology of Aurora Subglacial Basin, East Antarctica derived by an icedynamics-based interpolation scheme, The Cryosphere, 5, 551560, https://doi.org/10.5194/tc-5-551-2011, 2011.

Roberts, J., Galton-Fenzi, B. K., Paolo, F. S., Donnelly, C., Gwyther, D. E., Padman, L., Young, D., Warner, R., Greenbaum, J., Fricker, H. A., and Payne, A. J.: Ocean forced variability of Totten Glacier mass loss, Geol. Soc. S. P., 461, SP461-6, https://doi.org/10.1144/SP461.6, 2017.

Scambos, T., Bohlander, J., and Raup, B.: Images of Antarctic Ice Shelves, MODIS channel 2. National Snow and Ice Data Center, https://doi.org/10.7265/N5NC5Z4N, 2001 (updated 2018).

Scambos, T., Fahnestock, M., Gardner, A., and Klinger, M.: Global Land Ice Velocity Extraction from Landsat 8 (GoLIVE), Version 1.1, https://doi.org/10.7265/N5ZP442B, 2016.
Schoof, C.: Ice-sheet acceleration driven by melt supply variability, Nature, 468, 803-806, https://doi.org/10.1038/nature09618, 2010.

Shchepetkin, A. F. and McWilliams, J. C.: The regional oceanic modeling system (ROMS): a split-explicit, free-surface, topography-following-coordinate oceanic model, Ocean Model., 9, 347-404, 2005.

Sohn, H.-G., Jezek, K. C., and van der Veen, C. J.: Jakobshavn Glacier, West Greenland: 30 years of spaceborne observations, Geophys. Res. Lett., 25, 2699-2702, 1998.

Tamura, T., Ohshima, K. I., Fraser, A. D., and Williams, G. D.: Sea ice production variability in Antarctic coastal polynyas, J. Geophys. Res.-Oceans, 121, 2967-2979, 2016.

Thyng, K. M., Greene, C. A., Hetland, R. D., Zimmerle, H. M., and DiMarco, S. F.: True colors of oceanography: Guidelines for effective and accurate colormap selection, Oceanography, 29, 913, https://doi.org/10.5670/oceanog.2016.66, 2016.

Timmermann, R., Le Brocq, A., Deen, T., Domack, E., Dutrieux, P., Galton-Fenzi, B., Hellmer, H., Humbert, A., Jansen, D., Jenkins, A., Lambrecht, A., Makinson, K., Niederjasper, F., Nitsche, F., Nøst, O. A., Smedsrud, L. H., and Smith, W. H. F.: A consistent data set of Antarctic ice sheet topography, cavity geometry, and global bathymetry, Earth Syst. Sci. Data, 2, 261-273, https://doi.org/10.5194/essd-2-261-2010, 2010.

Todd, J. and Christoffersen, P.: Are seasonal calving dynamics forced by buttressing from ice mélange or undercutting by melting? Outcomes from full-Stokes simulations of Store Glacier, West Greenland, The Cryosphere, 8, 2353-2365, https://doi.org/10.5194/tc-8-2353-2014, 2014.

Vaughan, D. and Doake, C.: Recent atmospheric warming and retreat of ice shelves on the Antarctic Peninsula, Nature, 379, 328 331, https://doi.org/10.1038/379328a0, 1996.

Walter, J. I., Box, J. E., Tulaczyk, S., Brodsky, E. E., Howat, I. M., Ahn, Y., and Brown, A.: Oceanic mechanical forcing of a marineterminating Greenland glacier, Ann. Glaciol., 53, 181-192, 2012.

Young, D. A., Wright, A. P., Roberts, J. L., Warner, R. C., Young, N. W., Greenbaum, J. S., Schroeder, D. M., Holt, J. W., Sugden, D. E., Blankenship, D. D., and van Ommen, T. D.: A dynamic early East Antarctic Ice Sheet suggested by ice-covered fjord landscapes, Nature, 474, 72-75, https://doi.org/10.1038/nature10114, 2011.

Zhou, C., Zhou, Y., Deng, F., Songtao, A., Wang, Z., and Dongchen, E.: Seasonal and interannual ice velocity changes of Polar Record Glacier, East Antarctica, Ann. Glaciol., 55, 45-51, https://doi.org/10.3189/2014AoG66A185, 2014.

Zwally, H. J., Abdalati, W., Herring, T., Larson, K., Saba, J., and Steffen, K.: Surface melt-induced acceleration of Greenland ice-sheet flow, Science, 297, 218-222, https://doi.org/10.1126/science.1072708, 2002. 